NBER WORKING PAPER SERIES

\title{
THE EFFECTS OF CHANGES IN TAX LAWS ON CORPORATE REORGANIZATION ACTIVITY
}

Myron S. Scholes

Mark A. Wolfson

Working Paper No. 3095

NATIONAL BUREAU OF ECONOMIC RESEARCH

1050 Massachusetts Avenue

Cambridge, MA 02138

September 1989

We are grateful to the Arthur Young Foundation for financial support. We have benefitted from conversations with Alan Auerbach, Jeremy Bulow, Oliver Hart, Don Lessard, Mark Mazur, Mike Moore, Ed Outslay, James Poterba, John Shoven, Rob Vishny, and Jim Wheeler. This paper is part of NBER's research programs in Taxation and Financial Markets and Monetary Economics. Any opinions expressed are those of the authors not those of the National Bureau of Economic Research. 
NBER Working Paper \#3095

September 1989

\title{
THE EFFECTS OF CHANGES IN TAX LAWS ON CORPORATE REORGANIZATION ACTIVITY
}

\begin{abstract}
We present evidence that changes in tax laws passed in the 1980s, culminating with the Tax Reform Act of 1986, had a first order effect on observed merger and acquisition activity in the US. We also present evidence of increased reliance on certain institutional arrangements (unit management buyouts and going-private transactions) used to effect mergers and acquisitions that were designed to reduce the nontax costs of transacting, thereby enabling tax benefits to be realized in a larger number of mergers and acquisitions than might otherwise have occurred.

We begin with a "closed-economy" perspective, focusing on the effects of changes in tax laws on the demand for mergers and acquisitions of US corporations by US corporations. We then broaden the scope of inquiry by modeling and testing the effects of changes in tax law's on the demand for mergers and acquisitions of US corporations by foreign multinationals. Here we predict and present confirmatory evidence that while the 1986 Tax Act discouraged transactions among US corporations, it increased the demand for merger and acquisition transactions between US sellers and foreign buyers.
\end{abstract}

Myron S. Scholes

Stanford University

Graduate School of Business

Hoover Institution

Stanford, CA 94305
Mark A, Wolfson

Stanford University

Graduate School of Business

Hoover Institution

Stanford, CA 94305 
Changes in US tax laws in the 1980s have clearly affected the desirability of mergers and acquisitions. Of course, such transactions are motivated by myriad nontax factors as well: for example, a desire to exploit economies of scale or scope in operations, or a desire on the part of the incumbent management to engage in empire-building or further managerial entrenchment. ${ }^{1}$ But on the tax side, mergers and acquisitions may be prompted by several considerations: the presence of tax attribute carryforwards such as net operating losses, capital losses, investment tax credits, and foreign tax credits, among others, that might be "cashed in" more quickly and more fully by way of a merger; the desire to "step up the tax basis" of assets for depreciation purposes to their fair market value; the desire to sell assets to permit a change in the depreciation schedule to one that is more highly accelerated; and the desire to sell assets that have declined in market value to a level that is below their tax basis to permit an immediate tax deduction in an amount equal to the "unrealized" loss.

The desire to increase leverage and to avoid or postpone the taxation of dividend income to the shareholders are additional alleged tax motivations for mergers and acquisitions. For both of these claims, however, there exist imperfect substitutes for achieving these goals that neither require assets to be sold nor firms to be merged. ${ }^{2}$ Although these motivations are not a central focus of this study, Gilson, Scholes, and Wolfson (1987) describe the many available options for realizing these tax benefits prior to the 1986 Tax Act.

The Economic Recovery Tax Act (ERTA) of 1981 encouraged asset sales not only to effect a step-up in depreciable asset basis but also to effect a change in depreciation schedule to one that was much more accelerated (the so-called "accelerated cost recovery system" or ACRS). ${ }^{3}$

\footnotetext{
${ }^{1}$ For a discussion of nontax factors in takeovers, see Jensen (1986). For estimates of the tax savings associated with management buyouts during the 1980s, see Kaplan (1987) and Schipper and Smith (1988).

${ }^{2}$ Auerbach and Reishus (1988) indicate that increased leverage was not a feature observed in 318 large mergers they studied, occurring between 1968 and 1983.

${ }^{3} \mathrm{ACRS}$ depreciation, in conjunction with more generous investment tax credit provisions, increased the frequency with which firms experienced net operating loss and investment tax credit carryforwards. (See Auerbach and Poterba (1987) for empirical evidence on net operating
} 
The Installment Sales Revision Act, passed in October of 1980, aiso promoted asset sales by making installment sales a more effective way of reducing the present value of the tax costs to the seller of assets from capital gains and from the recapture of past depreciation as ordinary income. ${ }^{4}$ The Deficit Reduction Act (DRA) of 1984 withdrew some of the tax advantages of asset sales by extending modestly the depreciable lives of certain assets and by removing the opportunity to postpone the recapture of past depreciation through the use of installment sales.

The Tax Reform Act (TRA) of 1986 put nails in the tax-induced asset sales and mergers coffin along all of the tax dimensions that are important in motivating mergers and acquisitions involving domestic buyers. The $1986 \mathrm{Act}$ introduced less generous depreciation schedules; it increased the capital gains tax rate at both the corporate and personal level; it eliminated the so-called General Utilities doctrine, which had provided an ability to avoid a corporate-level capital gains tax on the difference between the market value and the adjusted tax basis of corporate assets sold or distributed in a planned corporate liquidation, ${ }_{\mathbf{5}}^{\mathbf{5}}$ it reduced substantially

loss carryforwards of public corporations for the 1981-1984 period.) The increase was undoubtedly exacerbated by the recession that occurred at that time. This, in conjunction with very high interest rates, provided an additional impetus to mergers in the post-ERTA period. High interest rates are relevant because carryforwards diminish in value when discount rates increase.

${ }^{4}$ To illustrate, suppose a corporation owns a depreciable asset that it acquired for $\$ 50$ million, on which depreciation of $\$ 15$ million has accumulated, leaving a tax basis in the property of $\$ 35$ million. If the asset is sold for its current market value of $\$ 75$ million, the corporation realizes a gain of $\$ 40$ million, of which the past depreciation of $\$ 15$ million is "recaptured" as ordinary income and the remaining $\$ 25$ million is a capital gain.

The new buyer may begin to depreciate the asset using a $\$ 75$ million tax basis, and if the seller first purchased the asset before 1981 and the asset is sold after $12 / 31 / 80$, the new, faster depreciation schedule is available to the buyer. Moreover, if the asset is sold for an installment note rather than cash, the capital gain (and, prior to the Deficit Reduction Act of 1984, the recapture tax) liability is frozen in nominal terms. The payment of tax is postponed until principal payments are received by the seller of the installment note. In addition, the capital gain is taxed at favorable rates, whereas the stepped-up depreciation deductions shelter ordinary income.

${ }^{5}$ The elimination of the General Utilities doctrine actually encouraged acquisitions of US companies by foreign investors residing in countries that have tax treaties with the US. The reason is that after the $1986 \mathrm{Tax}$ Act, subsidiaries that are at least $80 \%$-owned by their parents can still be liquidated tax-free into their parent. For US parents, this only postpones the day of reckoning: assets cannot be distributed out of the consolidated entity without attracting a tax. But if the subsidiary is liquidated into a foreign parent, the parent can then sell the assets and avoid a US tax entirely. This consideration may be especially important for investors residing 
the ability to use instaliment sales to postpone capital gains taxes; it increased the amount of ordinary income that must be recaptured on a corporate liquidation; it increased the proportion of the purchase price paid in excess of the fair market value of the tangible assets acquired that must be treated by the buyer as goodwill (nonamortizable for tax purposes but required to be amortized for financial reporting purposes); it introduced more stringent rules regarding the availability of net operating loss and other tax attribute carryforwards in the event of a merger; and it reduced marginal tax rates, thereby decreasing the potential gains 10 accelerating the usage of net operating loss carryforwards or to stepping up the depreciable basis of assets. 6

In addition to tax considerations, the pervasiveness of nontax costs of transacting have important effects on the desirability of mergers and acquisitions as well. Most important here are the costs that result from the current owners of the firm (or their agents) having information about the value of the firm not possessed by prospective buyers. A manifestation of these costs is the billions of dollars in investment banking, accounting, legal, and other third-party fees that are paid to intermediate trade among the differentially-informed buyers and sellers in merger and acquisition transactions.

Are these nontax costs important? Do they have a first-order effect on observed behavior? Answers to these questions are easy to find. For example, in the absence of these nontax costs, it is straightforward to show that broad classes of assets such as commercial and residential realty should have been sold by most owners each and every year prior to the effective date of the Deficit Reduction Act of $1984 .^{7}$ This is so whether the assets had declined in value to a level below their tax basis, in which case a sale would have enabled the "loss" to

in tax jurisdictions that do not tax profits earned abroad. For further discussion of the tax rules see Kleinbard and Duncan (1987).

6It has been argued that the introduction of the corporate alternative minimum tax provides the one new incentive to effect mergers following the $1986 \mathrm{Act}$. This incentive is overstated, however, because of the availability of an offsetting alternative minimum tax credit as well as many other alternative ways to reduce the bite of this tax.

${ }^{7}$ See Gilson, Scholes, and Wolfson (1987) for details. 
be recognized immediately for tax purposes; or whether the market value of the assets exceeded the tax basis, in which case an installment sale of the asset would have resulted in a step-up of the depreciable basis to the buyer along with a deferral of taxes on any depreciation recapture and capital gain to the seller until such time as principal payments were received on the instaliment note. In the extreme, an interest-only installment note with principal payments received far in the future would have resulted in a substantial elimination of the seller's taxes on the sale, in present value terms. ${ }^{8}$

On the other hand, the presence of costs to trade assets can reduce the frequency with which it is efficient to turn over assets to garner tax benefits. ${ }^{9}$ Indeed, one need not collect systematic evidence to reject the hypothesis that assets such as commercial and residential realty changed hands as frequently as annually. So the relevant question becomes: are the nontax costs of trading assets so large that they swamp the tax benefits of doing so?

We have argued elsewhere (Scholes and Wolfson, 1987) that in designing an organization, tax considerations and information-related transaction cost considerations are often in conflict with one another, and that a richer predictive theory of both tax planning and organizational design should emerge with a joint consideration of these interaction effects. In other words, in a world of costly contracting, wherein implementation of tax-minimizing strategies introduces significant costs along nontax dimensions, effective tax planning is substantially different from tax minimization.

In this study, we will present evidence that the changes in tax laws passed in the 1980s, culminating with the Tax Reform Act of 1986, had a first order effect on observed merger and acquisition activity in the US. We will also present evidence of increased reliance on certain institutional arrangements (management buyouts and going-private transactions) that were

\footnotetext{
${ }^{8}$ The calculus changed following the 1984 Tax Act, since installment sales no longer postponed the recapture tax on the sale of depreciable assets after the effective date of the Act.

${ }^{9}$ Scholes, Terry, and Wolfson (1989) model this phenomenon for real estate assets and present some empirical evidence on the use of installment sales and on property tumover rates.
} 
designed to reduce the nontax costs of transacting, thereby enabling tax benefits to be realized in a larger number of mergers and acquisitions than might otherwise have occurred.

We will begin with a "closedeconomy" perspective, focusing on the effects of changes in tax laws on the demand for mergers and acquisitions of US corporations by US corporations. We will then broaden the scope of inquiry by modeling and testing the effects of changes in tax laws on the demand for mergers and acquisitions of US corporations by foreign multinationals. Here we predict and present confirmatory evidence that while the 1986 Tax Act discouraged transactions among US corporations, it increased the demand for merger and acquisition transactions between US sellers and foreign buyers.

Appendix 1 contains a brief discussion of some of the more prominent tax rules and their implications for mergers and acquisitions, particularly for the 1980s. This discussion further motivates the empirical tests discussed below. Appendix 1 may be read at this juncture, but the less patient reader may proceed directly to the empirical evidence that follows.

\section{Closed Economy Analysis}

In this section, we present simple empirical evidence suggesting that the 1981 and 1986 Tax Acts had first-order effects on the level of aggregate merger and acquisition activity in the US, despite the presence of transaction cost impediments to trade. We begin by considering the dollar value of mergers and acquisitions in the period surrounding the 1981 Act. Recall that this tax bill, by virtue of its introduction of very rapid depreciation under the accelerated cost recovery system, should have stimulated mergers and acquisitions.

Table 1 displays the annual values of mergers and acquisitions from 1968 through 1987 in nominal dollars, constant 1986 consumer price index (CPI) dollars, and constant 1986 S\&P 500 stock index dollars. The data source for nominal values is W.T. Grimm and Company (Mergerstat) for 1968-1985 and Mergers \& Acquisitions for 1986 and 1987. There is a slight 
downward bias in the apparent annual trend for 1986 and 1987, since Grimm uses a minimum $\$ 500,000$ cutorf value for a transaction to be included in its database, whereas Mergers $\&$ Acquisitions uses a $\$ 1$ million cutoff value. The dollar volume of merger and acquisition activity increased $86 \%$ in nominal terms between 1980 and 1981 , from $\$ 44.35$ billion to $\$ 82.62$ billion. ${ }^{10}$ The constant CPI dollar increase was $70 \%$, and the constant S\&P 500 dollar increase was $96 \%$. In all cases, the percentage increase was approximately twice as large as the next largest percentage increase in annual merger and acquisition activity over the 1970-1986 period.

Although not reflected in Table 1, the increase in activity in 1981 did not occur uniformly throughout the year, as might be expected. The 1981 Act was not signed into law until August of 1981 , although its passage was widely anticipated much earlier in the year. Moreover, while the accelerated cost recovery system for depreciable property was made effective retroactively to January 1, 1981, this could not have been fully anticipated at the beginning of 1981. It is worth noting that merger and acquisition activity in the first quarter of 1981 was no higher in nominal dollar value than during the fourth quarter of 1980 , whereas there was a doubling in the dollar value of activity during the second quarter of 1981 and an additional increase of $40 \%$ in activity during the third quarter of 1981 . This increases our confidence that the increase in activity in 1981 was at least in part tax-driven.

Looking over a somewhat longer horizon, the average annual dollar value of mergers and acquisitions in the six years between the effective dates of the 1981 Act (January 1, 1981) and the 1986 Act (January 1, 1987 for most of the relevant provisions) was $\$ 118.4$ billion. This is more than four times as large as during the six years immediately preceding the effective

\footnotetext{
${ }^{10}$ Throughout the paper, where aggregate dollar values are reported they are based on the subset of transactions for which dollar values are available. Dollar values are not always a vailable, for example, in transactions involving private sellers.
} 
TABLE 1.

MERGER AND ACQUISITION VALUES: NOMNAL DOLLAR, CONSTANT DOLLAR, AND CONSTANT STOCK INDEX AMOUNTS ANNUAL FIGURES: $1968-1987$

\begin{tabular}{|c|c|c|c|}
\hline YEAR & $\begin{array}{l}\text { NOMINAL DOLLAR } \\
\text { VALUE OF } \\
\text { M\&A ACTIVITY } \\
\text { (\$BILLIONS) }\end{array}$ & $\begin{array}{l}\text { CONSTANT } 1986 \\
\text { DOLLAR VALUE } \\
\text { OF M\&A ACTIVITY } \\
\text { (\$BILLIONS) }\end{array}$ & $\begin{array}{r}\text { CONSTANT } 19 \\
500 \text { INDEX V } \\
\text { OF M\&A ACT } \\
\text { (\$BILLION }\end{array}$ \\
\hline $\begin{array}{l}1968 \\
1969\end{array}$ & $\begin{array}{l}43.61 \\
23.71\end{array}$ & & \\
\hline $\begin{array}{l}1970 \\
1971 \\
1972 \\
1973 \\
1974\end{array}$ & $\begin{array}{l}16.42 \\
12.62 \\
16.68 \\
16.67 \\
12.47\end{array}$ & $\begin{array}{l}42.48 \\
31.15 \\
39.62 \\
37.42 \\
25.75\end{array}$ & $\begin{array}{l}86.90 \\
58.44 \\
64.93 \\
76.01 \\
77.32\end{array}$ \\
\hline $\begin{array}{l}1975 \\
1976 \\
1977 \\
1978 \\
1979 \\
1980\end{array}$ & $\begin{array}{l}11.80 \\
20.03 \\
21.94 \\
34.18 \\
43.54 \\
44.35\end{array}$ & $\begin{array}{l}22.23 \\
35.77 \\
37.09 \\
53.93 \\
63.06 \\
58.88\end{array}$ & $\begin{array}{r}53.33 \\
73.12 \\
86.28 \\
126.15 \\
135.66 \\
104.36\end{array}$ \\
\hline $\begin{array}{l}1981 \\
1982 \\
1983 \\
1984 \\
1985 \\
1986\end{array}$ & $\begin{array}{r}82.62 \\
53.76 \\
73.08 \\
122.22 \\
179.77 \\
201.37\end{array}$ & $\begin{array}{r}100.04 \\
61.52 \\
80.45 \\
129.02 \\
183.23 \\
201.37\end{array}$ & $\begin{array}{l}204.46 \\
109.57 \\
121.59 \\
191.36 \\
212.97 \\
201.37\end{array}$ \\
\hline 1987 & 174.99 & 168.77 & 166.30 \\
\hline $\begin{array}{l}1970-1980 \\
1975-1980 \\
1981-1986\end{array}$ & $\begin{array}{r}22.79 \\
29.30 \\
118.80\end{array}$ & $\begin{array}{r}40.67 \\
45.16 \\
125.94\end{array}$ & $\begin{array}{r}85.68 \\
96.48 \\
173.55\end{array}$ \\
\hline $\begin{array}{l}6 / 1975-80 \\
6 / 1970-80\end{array}$ & $\begin{array}{l}4.05 \\
5.21\end{array}$ & $\begin{array}{l}2.79 \\
3.10\end{array}$ & $\begin{array}{l}1.80 \\
2.03\end{array}$ \\
\hline
\end{tabular}

ATA SOURCES: W.T. GRLMM (MERGERSTAT) FOR 1968-1985 NOMINAL VALUES MERGERS \& ACQUISITIONS FOR 1986-1987 NOMNAL VALUES 1985 ECONOMIC REPORT OF THE PRESIDENT INDUSTRY WEEK FOR CONSUMER PRICES 1985-1987 IBBOTSON ASSOCLATES (STOCKS, BONDS, BILLS AND INFLATION) FOR S\&P 500 INDEX VALUES 
date of the 1981 Act (and more than five times as large as during the average over the eleven ycars dating back to 1970).

In constant dollar terms, the dollar value of mergers and acquisitions during 1981-86 is 2.8 times as large as during $1975-80$ (and 3.1 times as large as the annual average during the $1970-80$ period). Adjusted for changes in the consumer price index, mergers and acquisitions during 1981-86 rank first, second, third, fourth, fifth, and seyenth over the seventeen-year period 1970-86. The sum of these ranks (22) for 1981-86 could have been this low or lower purely by chance less than once in three thousand. 11,12

The dramatic increase in merger activity that began contemporaneously with the passage of the Economic Recovery Tax Act of 1981 is not the only "merger wave" of the twentieth century. Three other periods of unusual merger activity have occurred: the late $1890 \mathrm{~s}$ to early $1900 \mathrm{~s}$, the $1920 \mathrm{~s}$, and the $1960 \mathrm{~s}$. It may be of interest to note that the termination of the merger wave of the 1960 s was accompanied by several regulatory events that discouraged such transactions: the Williams Amendments that increased the difficulty and the costs of effecting tender offers; the issuance of Accounting Principles Bcard Opinions 16 and 17, reducing the flexibility of acquiring fims in regards to their accounting for mergers (forcing many acquiring firms to increase depreciation expense, cost of goods sold, and goodwill amortization); and the passage of the Tax Reform Act of 1969 that, among other things, introduced restraints on the transferability of certain tax attributes such as net operating loss carryforwards.

\footnotetext{
${ }^{11}$ Adjusted for the level of the Standard and Poor's 500 stock index, the rankings during 1981-86 are first, second, third, fourth, seventh, and eighth out of seventeen; such an extreme ranking could occur by chance less than once in a thousand. In nominal dollars, the rankings during 1981 . 86 are first, second, third, fourth, fifth, and sixth out of seventeen. Such an extreme ranking could occur by chance less than once in six thousand.

12 While the significance levels reported for the rank sum tests are in some respects conservative (in that they rely only on ordinal information), they also assume independence across observations, a condition that may well be violated. Consequently, significance levels should be viewed with caution.
} 
Schipper and Thompson (1983) document a negative response in the value of equity to these regulatory events for firms engaged in active acquisitions programs. Moreover, the data in Table 1 display an abrupt and dramatic decline in merger activity from the peak in 1968: W.T. Grimm \& Co., in their Mergerstat annual publication, reports $\$ 43.6$ billion of mergers and acquisitions in $1968, \$ 23.7$ billion in 1969 and an average of $\$ 14.4$ billion per year for the 1970 1975 period, a decline of $67 \%$ in nominal terms (and, of course, larger in real terms) from 1968.

As a note of caution, however, it is also worth emphasizing that we have not controlled for contemporaneous nontax factors that may have influenced merger activity over the survey period. For example, the Reagan administration has been viewed as being relatively passive in the antitrust arena, which removes one impediment to mergers and acquisitions. On the other hand, it is not clear that tax policy in general, and the provisions of the 1981 Act in particular, should be viewed as being independent of antitrust policy (or, indeed, other regulatory policies such as those relating to foreign trade). Still, the internal validity of our investigation and inferences would be enhanced if we had a model to control for such factors. Unfortunately, such a model is not readily available, and we take but a small step here towards repairing that gap in the literature.

Among the explanations that have appeared in the institutional literature for the merger activity in the 1980 s is the development of the "junk" (i.e., high risk/high yield) bond market. As reported in Taggart (1988), public issues of junk bonds as a fraction of total public bond issues increased from $6.3 \%$ in the $1977-80$ period to $14.8 \%$ in the $1981-86$ period. It is also interesting to note that Drexel Burnham began selling junk bonds to effect leveraged buyouts in 1981.

Two comments are in order here. First, Taggart cites evidence suggesting that junk bonds were hardly used in 1984 and 1985 in mergers and acquisitions. Drexel Bumham estimated that such securities were associated with $1.4 \%$ and $2.7 \%$ of total merger financing in 1984 and 1985 , 
respectively, while Morgan Stanley estimated that junk bonds accounted for $2.6 \%$ and $4.5 \%$ of the merger financing in those years. Second, even this level of development of this market may be due, at least in part, to a tax-induced demand.

\section{Evidence Relating to the Tax Reform Act of 1986}

As indicated earlier, the restructuring of the Tax Code in 1986 should have reduced substantially the incentive of US firms to buy other US firms for tax purposes. Taxpayers, however, were given an advance warning of a calendar quarter's duration of the massive changes to take place. The law was passed early in the fourth quarter of 1986 , and there was substantial uncertainty as to whether it would pass much before this time; but the changes in rules did not go into effect, with respect to depreciation, installment sales, net operating losses, ordinary income recapture items, the General Utilities doctrine, and both ordinary and capital gains tax rates, until January $1,1987$.

Table 2 displays quarterly merger and acquisition activity (transactions between US companies only) in nominal dollar, constant 1987-4 CPI dollar, and constant 1987-4 S\&P 500 Index dollar amounts for the nine quarters centered on 1986-4, the quarter in which the 1986 Act was passed. The dollar volume of mergers and acquisitions during the fourth quarter of 1986 of $\$ 64.65$ billion represents a record, in both nominal and real terms, over at least the past fifty years. It exceds the average volume for the eight quarters surrounding it by $85 \%$ in nominal dollars, $86 \%$ in constant dollars, and $93 \%$ adjusted for the level of the S\&P 500 stock index.

While these data provide clear evidence of a bulge in activity during the fourth quarter of 1986, we are also interested in documenting a decline in activity post tax reform relative to pre tax reform. Table 2 documents a decline in mergers and acquisitions from the four quarters preceding tax reform to the four quarters succeeding tax reform by $20 \%$ in 
TABLE 2.

MERGER AND ACQUISITION VALUES: NOMINAL DOLLAR, CONSTANT DOLLAR, AND CONSTANT STOCK INDEX AMOUNTS QUARTERLY FIGURES: $1985-4$ THROUGH 1987-4

TRANSACTIONS BETWEEN US COMPANIES ONLY

\begin{tabular}{|c|c|c|c|c|c|c|}
\hline QUARTER & $\begin{array}{c}\text { NOMNAL } \\
\text { AMOUNT } \\
\text { (\$BILLIONS) }\end{array}$ & $\begin{array}{l}\text { RANK } \\
\text { EXCL } \\
86-4\end{array}$ & $\begin{array}{c}\text { CONSTANT } \\
\text { 87-4 CPI } \\
\text { AMOUNT } \\
\text { (\$BILLIONS) }\end{array}$ & $\begin{array}{c}\text { RANK } \\
\text { EXCL } \\
86-4\end{array}$ & $\begin{array}{c}\text { CONSTANT } \\
87-4 \text { S\&P } \\
\text { AMOUNT } \\
\text { (\$BILIONS) }\end{array}$ & $\begin{array}{c}\text { RANK } \\
\text { EXCL } \\
86-4\end{array}$ \\
\hline $1985-4$ & 45.93 & 1 & 48.60 & 1 & 57.26 & 1 \\
\hline $1986-1$ & 29.97 & 7 & 31.65 & 7 & 32.75 & 5 \\
\hline $1986-2$ & 44.55 & 2 & 47.15 & 2 & 45.97 & 2 \\
\hline $1986-3$ & 34.86 & 4 & 36.65 & 3 & 38.67 & 3 \\
\hline SUM & 155.31 & 14 & 164.05 & 13 & 174.65 & 11 \\
\hline AVG & 38.83 & & 41.01 & & 43.66 & \\
\hline $1986-4$ & 64.65 & & 67.44 & & 68.03 & \\
\hline $1987-1$ & 21.66 & 8 & 22.38 & 8 & 18.78 & 8 \\
\hline $1987-2$ & 32.97 & 6 & 33.63 & 6 & 27.20 & 6 \\
\hline $1987-3$ & 33.66 & 5 & 33.96 & 5 & 26.04 & 7 \\
\hline $1987-4$ & 35.82 & 3 & 35.82 & 4 & 35.82 & 4 \\
\hline SUM & 124.11 & 22 & 125.79 & 23 & 107.84 & 25 \\
\hline$A V G$ & 31.03 & & 31.45 & & 26.96 & \\
\hline PROB* & & .1714 & & .1000 & & .0286 \\
\hline
\end{tabular}

* PROB DENOTES THE PROBABILITY THAT THE SUM OF THE RANKS IN THE FOUR QUARTERS PRECEDING 1986-4 COULD BE AS LOW OR LOWER THAN THE SUM OF THE RANKS IN THE FOUR QUARTERS SUCCEEDNG 1986-4 BY CHANCE ALONE.

DATA SOURCES: MERGERS \& ACQUISITIONS FOR NOMINAL VALUES INDUSTRY WEEK FOR CONSUMER PRICES

IBBOTSON ASSOCIATES (STOCKS, BONDS, BILLS AND INFLATION) FOR S\&P 500 INDEX VALUES 
nominal dollars, $23 \%$ in constant dollars and $38 \%$ adjusted for the level of stock prices as reflected in the S\&P 500 index. Using a simple rank sum test, we can reject the hypothesis that the level of post-reform activity was drawn from a distribution with at least as large a mean as was the pre-reform activity, adjusted for changes in consumer prices and the S\&P 500 stock index, at levels of .1000 and .0286 , respectively. ${ }^{13}$ In nominal dollars, the decline in activity is not significant at conventional levels using only rank information. But the decline in merger and acquisition activity of $\$ 31$ billion ( $\$ 124$ billion $-\$ 155$ billion) is larger than any annual decline between 1970-1986. This could have occurred by chance with probability equal to .0625 . While we have not run parametric tests of whether the 1986 Act gave rise to a reduction in merger and acquisition activity, we note that the $22 \%$ decline in activity (in nominal dollar terms) stands in contrast to the average increase of over $35 \%$ during the six years following passage of the 1981 Act.

Table 2 fails to incorporate the fact that merger and acquisition activity has seen a secular increase since the early 19705. For example, a comparison of the average level of merger and acquisitions in the five years ending in 1975 versus that ending in 1980 reveals an annual growth rate of $18.48 \%$ in nominal dollar terms and $9.75 \%$ in both constant CPI dollars and constant S\&P 500 index terms. While the growth rate in mergers and acquisitions was considerably higher in the five years ending in 1985 , this should be due at least in part to the introduction of tax legislation.

If the values in Table 2 were detrended even for the more modest growth rates experienced in the decade preceding the introduction of the 1981 Tax Act, the results become much more striking. Significance levels drop to $1.43 \%$ in all three comparisons. The detrended

${ }^{13}$ It is possible that the reduced level of activity in 1987 simply represents an acceleration of transactions that would otherwise have been completed in 1987 into the fourth quarter of 1986. Evidence of activity in 1988 and 1989 should shed additional light on this possibility. In addition, evidence to be presented in the "open economy" section of this paper supports the claim that the 1986 Act had both transitory and permanent effects on merger and acquisition activity. 
decline in activity from the four quarters preceding 1986-4 to the four quarters following 1986-4 is $37 \%, 32 \%$, and $45 \%$, respectively, in nominal, constant CPI, and constant S\&P 500 index terms.

\section{Nontax Costs of Reorganization and Transactional Responses}

The evidence presented thus far suggests very strongly that tax law changes passed in 1981 and 1986 were associated with interruptions in the time series process of merger and acquisition activity. We have also discussed casual evidence of nontax costs that diminish the level of activity relative to what would be observed if tax minimization were the goal of corporate managers. In this section, we inquire as to whether there is any evidence of organizational arrangements designed to reduce the magnitude of nontax costs in tax-motivated transactions. Here we have two things to report, one involving management buyouts and the other involving going-private transactions.

At the broadest level of analysis, we can think of merger and acquisition transactions as being motivated by two categories of economic forces: tax factors and nontax factors. We argued earlier that tax-motivated transactions should have increased in importance during the 19811986 period. Suppose that the transaction costs associated with the sellers of assets being better informed than prospective buyers about asset values are lower when shareholders sel! the assets to incumbent managers than when the assets are sold to outsiders. To take an extreme example, suppose that the value of the assets available for sale is commonly known by the current management group and the independent members of the Board of Directors, who must approve the terms of sale. Prospective non-manager buyers from the outside, however, are less well-informed regarding asset values. Then ignoring risk-sharing considerations, the nontax costs of a sale will be lower in a transaction with management relative to one involving outsiders.

Suppose further that the nontax gains to a merger or acquisition are idiosyncratic to managers and outsiders (although the range of nontax benefits is much wider for outsiders), but 
that the tax-related gains are common to both prospective buyer groups. ${ }^{14}$ When the nontax gains are large, it is outsiders that are most often the source of this value. They can, therefore, often afford to bid more for the right to purchase the firm (or a division) than can incumbent management despite their disadvantage along the hidden information dimension. But when the nontax benefits of the transaction are small selative to the tax benefits, incumbent management will typically be the most efficient purchasers due to their advantage along the hidden information dimension. The 1981 Act should have increased the frequency of cases in which the common tax benefits are large relative to the nontax benefits of mergers and acquisitions. As a consequence, we should observe an increase in the proportion of transactions involving maragement buyouts.

One way to capture what we have in mind here is to suppose that prior to the introduction of the 1981 tax subsidy, the distribution of values that outside bidders and incumbent mangers can create through takeover are uniformly distributed over the intervals depicted in the figure below. Assume further that draws from these value distributions are independent.
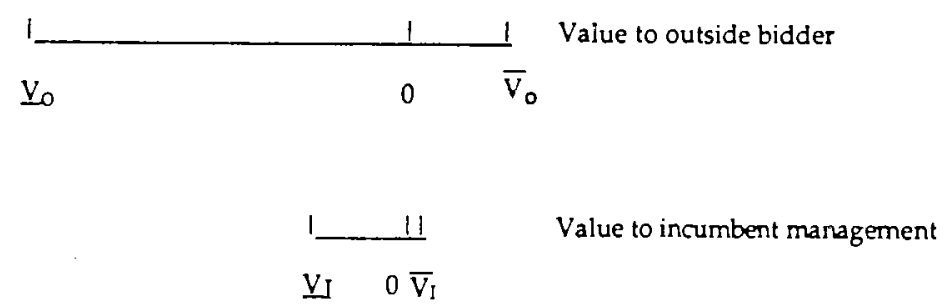

Note that $E\left(\tilde{V}_{O}\right)$ and $E\left(\tilde{V}_{1}\right)$ are well below zero, where - denotes a random variable, $V_{O}$ denotes the value to outsiders, net of transactions costs, $V_{I}$ denotes the value to insiders, and $E$ is an expectation operator. Note also that $\bar{V}_{O}>\bar{V}_{I}$ and that $\bar{V}_{O} /\left(\bar{V}_{0}-\underline{V}_{0}\right)$ is large relative to $\bar{V}_{I}$ $/\left(\bar{V}_{I}-V_{J}\right)$. Finally, $\bar{V}_{I}$ is near zero. If a change in control occurs whenever $V_{I}$ or $V_{0}$ has positive value, and the firm is always purchased by the group that values it most highly, then these

\footnotetext{
${ }^{14}$ In truth, a component of the tax-related gain may increase with the level of nontax gains to merger, as discussed in Gilson, Scholes and Wolfson (1987).
} 
distributions ensure that takeovers are relatively rare and that management buyouts are even rarer.

Now suppose that a tax subsidy to acquisition is introduced that shifts both distributions to the right. It is easily seen that there will be a relative increase in the probability that $V_{I}>V_{0}$ and $V_{I}>0$; that is, insiders value the acquisition more highly than both outsiders and existing shareholders.

W.T. Grimm and Company's annual Mergerstat volumes inciude annual data on management buyouts of divisions and total divestitures beginning in 1978. As Table 3 indicates, there was a significant increase in the fraction of divestitures effected by way of a management buyout in the $1981-86$ period relative to the $1978-1980$ period. More specifically, the fraction of divestitures in which a public announcement was made that an executive of the parent company or members of the selling division's management were included among the purchasing group increased from $6.93 \%$ during the $1978-1980$ period to $12.22 \%$ during the $1981-1986$ period. While the total number of divestitures increased by $34 \%$ from 746 per year during $1978-1980$ to 1002 per year during 1981-1986, the number of unit management buyouts increased by $137 \%$ from 51.7 per year to $\mathbf{1 2 2 . 5}$ per year. Whereas the maximum fraction of unit management buyouts to total divestitures in any given year in the $1978-1980$ period was $7.85 \%$, the minimum fraction was $10 \%$ in 1981-1986, and this occurred in 1981, the transition year. Using only rank information for these fractions, the increased management buyout activity after 1980 is statistically significant at the .0119 level: 


\section{TABLE 3.}

UNIT MANAGEMENT BUYOUTS ANNUAL FIGURES: $1978-1986$

$\begin{array}{lcccc}\text { YEAR } & \begin{array}{c}\text { TOTAL } \\ \text { DIVESTITURES }\end{array} & \begin{array}{c}\text { MANAGEMENT } \\ \text { BUYOUTS }\end{array} & \begin{array}{c}\text { PERCENTAGE } \\ \text { MGT BUYOUTS }\end{array} & \text { RANK } \\ 1978 & & 49 & 6.0 \% & 9 \\ 1979 & 820 & 59 & 7.9 \% & 7 \\ 1980 & 752 & 47 & 7.1 \% & 8 \\ \text { SUM } & 666 & 155 & 6.9 \% & 24 \\ 1981 & 2238 & 83 & 10.0 \% & 6 \\ 1982 & 830 & 115 & 13.1 \% & 3 \\ 1983 & 875 & 139 & 14.9 \% & 1 \\ 1984 & 932 & 122 & 13.6 \% & 2 \\ 1985 & 900 & 132 & 10.8 \% & 5 \\ 1986 & 1218 & 144 & 11.4 \% & 4 \\ \text { SUM } & 1259 & 735 & 12.2 \% & 21 \\ \text { PROB } & 6014 & & & .0119\end{array}$

* PROB DENOTES THE PROBABILITY THAT THE SUM OF THE RANKS IN THE THREE YEARS PRECEDING 1981 COULD BE AS HIGH OR HIGHER THAN THE ACTUAL VALUE (OF 24) BY CHANCE ALONE.

DATA SOURCE: W.T. GRIMM AND COMPANY (MERGERSTAT)

NOTE: $\quad$ DATA UNAVAILABLE PRIOR TO 1978 
The results are even more striking in dollar value terms. Whereas the annual dollar value of merger and acquisitions increased by a factor of three between 1978-1980 and 1981-1986, the annual dollar value of unit management buyouts increased by a factor in excess of twenty.

\section{Going-Private Transactions}

The second source of evidence we have to present suggesting an increase in transactional arrangements designed to reduce the nontax costs associated with engaging in tax-motivated mergers and acquisitions relates to public companies that were taken private. Since going* private transactions are often effected by incumbent managers in a buyout transaction, we can use data on going-private transactions as a further test of our management buyout story. Since going-private transaction data involves cases in which the entire firm is sold and unit management buyout data involves the sale of divisions only, and there is no overlap in transactions, the two tests are independent. Moreover, a transaction designed to step up the depreciable basis of assets for tax purposes typically requires an increase in depreciation for financial reporting purposes as well (due to "purchase consolidation" rules). If this is perceived as being costly, it provides further incentive for the firm to be taken private.

W.T. Grimm and Company has been collecting and reporting data on going-private transactions since 1979. As Table 4 reveals, there was a clear increase in the fraction of public takeovers that resulted in companies being taken private in 1981-1986 relative to 1979-1980. Whereas the average number of going-private transactions was $7 \%$ of the total of public takeovers in the earlier period, it was 19\% during 1981-1986. Once again, 1981 was a transition year with $10.1 \%$ of the public takeovers being going-private transactions. Using only the information reflected in the ranks of these fractions, the relatively low level of going-private activity in the 1979-1980 period could have occurred by chance alone with probability equal to $4 \%$. In addition, the annual average dollar volume of going-private transactions increased by 
TABLE 4.

GOING PRTATE TRANSACTIONS

ANNUAL FIGURES: 1979.1986

$\begin{array}{lccc}\text { YEAR } & \begin{array}{c}\text { DOLLAR VALUE OF GOING } \\ \text { PRIVATE TRANSACTIONS } \\ \text { (SBILLIONS) }\end{array} & \begin{array}{c}\text { PERCENTAGE } \\ \text { GOING } \\ \text { PRIVATE* }\end{array} & \text { RANK } \\ 1979 & 0.6 & & \\ 1980 & 1.0 & 6.4 \% & 8 \\ & & 7.5 \% & 7 \\ 1981 & 2.3 & 10.1 \% & 6 \\ 1982 & 2.8 & 17.2 \% & 5 \\ 1983 & 7.1 & 19.0 \% & 4 \\ 1984 & 10.8 & 27.0 \% & 1 \\ 1985 & 24.1 & 22.6 \% & 2 \\ 1986 & 20.2 & 19.7 \% & 3 \\ & & & \\ \text { PROB }^{* *} & & & .0357\end{array}$

* as a fraction of the total number of public takeovers.

** PROB DENOTES THE PROBABILITY THAT THE SUM OF THE RANKS IN THE TWO YEARS PRECEDING 1981 COULD BE HAS HIGH OR HIGHER THAN THE ACTUAL VALUE (OF 15) BY CHANCE ALONE.

DATA SOURCE: W. T. GRIMM AND COMPANY (MERGERSTAT)

NOTE: $\quad$ DATA UNAVAILABLE PRIOR TO 1979 
a factor of fourteen between the two periods, whereas the dollar volume of all mergers and acquisitions increased by a factor of only 2.7 .

\section{Restructuring from Corporate to Partnership Form}

Another interesting implication of the Tax Reform Act of 1986 insofar as corporate restructuring is concerned relates to the desirability of the corporate versus partnership form of organization. The 1986 Act reconfirms, in fact places greater emphasis on, double taxation of income eamed in corporate form. Prior to the $1986 \mathrm{Act}$, the maximum corporate tax rate was a bit below the maximum personal tax rate, and the second round of corporate tax, that assessed to shareholders upon disposition of ownership interest, was very low due to favorable statutory capital gains tax rates, myriad opportunities to postpone or avoid the payment of the tax, and opportunities to time the realization of the gain to coincide with a period in which the taxpayer faced a low tax rate. The 1986 Act not only set the maximum corporate tax rate of $34 \%$ well above the personal tax rate on high-income individuals of $28 \%$, it also raised substantially the shareholder-level tax. This means that for successful businesses, the corporate form of organization has become significantly less attractive from a tax standpoint relative to partnerships than it was under prior law, especially for new investment as opposed to reinvestment of retained eamings. .5

It is interesting to note that the US is "swimming against the current," relative to the rest of the world, in insisting on double taxation of corporate income. In many other industrialized countries, including Canada, Italy, Australia, France, West Germany, and the UK, corporate and personal income taxes are integrated by granting corporate tax credits to sharcholders that receive dividends and taxing shareholders on a grossed-up amount of dividend income (grossed up, that is, to include the tax credit for corporate taxes paid

15The claim that the 1986 Act favored the partnership form of organization over the corporate form is actually somewhat controversial. For a different perspective, see Fullerton, Gillette, and Mackie (1987) and the references cited therein. 
indirectly). In other countries, single-level taxation of corporate income is approximated by levying very low tax rates on capital gains (or dividends), thereby making the shareholderlevel tax relatively unimportant.

Despite the tax advantages of the noncorporate form of organization under the Tax Reform Act of 1986, very few public firms converted from corporate to noncorporate form. There were some conversions, but not very many. The tax and transaction costs associated with converting to partnership apparently outweighed the perceived benefits for nearly all publicly-traded corporations. ${ }^{16}$ But while there are both tax and nontax costs to converting from corporate to partnership form, it seems reasonable to suppose that the nontax costs are Jelatively small for closely-held private corporations.

In this regard, it is especially interesting to consider the evidence on the number of socalled S Corporation elections made during 1985 and 1986. An S Corporation is a corporation that in most important respects is taxed as a partnership. The requirements to qualify include that the organization must have a relatively small number of shareholders (35), it must be incorporated or organized in the US, and it can issue only one class of stock.

In 1985, there were approximately $75,000 \mathrm{~S}$ Corporation elections. In the five weeks spanning the end of 1986 and the beginning of 1987 there were approximately $225,000 \mathrm{~S}$ Corporation elections, or three times as many (over this five-week period) as occurred throughout all of calendar $1985 .{ }^{17}$

\footnotetext{
16 For example, one concern on the tax dimension may have been a perceived possibility of adverse changes in rules governing publicly-traded firms that converted to partnership form. Indeed, the 1987 Act requires that most newly created public partnerships be taxed as corporations. Moreover, corporations need not necessarily convert their legal organizational form to achieve something close to the single-level taxation that partnerships enjoy. There exist many arrangements that result in a tax-deductible distribution of corporate profits (e.g., income-participation bonds and their equivalents, incentive compensation arrangements, and income-shifting joint venture partnerships).

17 Tax Notes $(2 / 1 / 88)$, p. 434, quoting Ronald Per Iman.
} 


\section{Open Economy Perspective}

We have presented both arguments and evidence suggesting that the Tax Reform Act of 1986 discouraged mergers and acquisitions, but our arguments viewed the US as a closed econamy. When nonUS investors face tax rules and investment opporturity sets that differ from those faced by US taxpayers, and where capital is allowed to fow across tax jurisdictions, changes in US tax rules can affect investment incentives of US and nonUS taxpayers differently.

Given differences in statutory tax rates across tax jurisdictions, foreign investors should find investment in the US more attractive post tax reform than before. The US has become a tax haven relative to many European countries as well as such countries as Japan, Canada, and Australia, all of which face higher corporate tax rates than US corporations. Investors in such countries may place a higher value on the assets held by US investors than US investors place on them; or at a minimum, the changes in US tax laws should increase the frequency with which nonUS investors place a higher value on US assets.

In other words, changes in tax rules may alter the natural tax clienteles (i.e., the sorting of taxpayers into their most tax-preferred investment and financing habitats) internationally. As a result, agents trade assets (mitigated as always by the tax and nontax costs of trading), because the relative valuations of such assets have changed in response to the new tax rules.

Our characterization of the US as a tax haven for investment post the 1986 Act may appear at odds with the claim that corporate taxes in the US were supposed to have been increased by $\$ 100$ billion under the law, primarily from elimination of investment tax credits and the reduction in the acceleration of depreciation. The resolution of this apparent conflict lies in recognizing that fewer assets will bear implicit taxes under the 1986 Act. Since more taxes will be explicit, the before tax rates of retum on US investment should increase. Given the increase in explicit taxes, this does not make investment to US investors more attractive, 
but it does make investment to high-tax nonUS investors more attractive. For a highly-taxed foreign investor, most explicit taxes paid in the US will be fully refundable upon repatriation of US earnings (through foreign tax credit mechanisms), whereas implicit taxes are often only tax-deductible but not creditable against taxes paid in the home country. ${ }^{18}$ The argument outlined above is developed more fully in Scholes and Wolison (1990).

The Tax Reform Act of 1986 favored foreign acquisitions of US businesses for another important reason. As discussed earlier, the Act raised the shareholder-level tax on capital gains. Foreign investors in countries with integrated tax systems, or in countries that otherwise tax capitai gains favorably, may largely be able to avoid the shareholder-level tax. ${ }^{19}$ As a consequence, such foreign investors should acquire relatively more equity interests in US businesses relative to US investors.

Next, we turn to empirical evidence to test whether foreign incentives to purchase US interests increased following the introduction of the Tax Reform Act of 1986. In particular, we compare merger and acquisition activity between US companies (as presented in Table 1) to that in which non US companies are represented on the buy side (see Table 5) around the time of the passage of the 1986 Act in the US.

Recall that the dollar volume of acquisitions of US firms by US companies increased by $85 \%$ during the fourth quarter of 1986 relative to the average during the eight quarters

\footnotetext{
28 An implication of this argument is that we would expect the increase in demand by foreign investors to be greatest for those US businesses that invest heavily in depreciable personal and real property (e.g., plant and equipment). This argument applies only to countries that impose taxes on worldwide profits and grant tax credits for foreign taxes paid. Japan and the UK operate this way. Other countries, such as France and the Netherlands, have so-called territorial tax systems, where active income earned in foreign jurisdictions is not taxed by the home country. A third category of tax systems is exemplified by Canada and West Germany. While these countries have a worldwide tax system, they exempt income earned (and dispense with granting foreign tax credits for taxes paid) in countries with which they have tax treaties.

19 Although integrated tax systems generaily do not permit full integration with corporate taxes paid in foreign jurisdictions, favorable "stacking rules" for domestic earnings ensure that double taxation will be largely avoided on foreign income as long as domestic profits are sufficient.
} 
surrounding this period. More precisely, it increased by $66 \%$ in the fourth quarter of 1986 relative to the average over the four preceding quarters. Then, as predicted, acquisitions dropped over the four quarters of 1987 to a level roughly $20 \%$ below that in the four quarters preceding $1986-4$.

In comparison, the dollar value of US acquisitions by nonUS companies in 1986-4 increased $430 \%$ to $\$ 15.52$ billion relative to the average over the preceding four quarters of $\$ 2.93$ billion. ${ }^{20}$ The level of activity during the fourth quarter of 1986 alone exceeded by $39 \%$ the average annual dollar volume of such activity recorded by W. T. Grimm and Company in their annual Mergerstat volume for the 1981-1985 period.

Moreover, while the level of acquisitions activity declined over the four quarters of 1987, relative to $1986-4$, to $\$ 11$ billion per quarter, the level of acquisitions in the four quarters of 1987 was 3.74 times as high as during the four quarters preceding $1986-4 . .^{21}$ Using a simple rank-sum test, the ranking differences (in nominal dollars, constant dollars, or adjusted for changes in the S\&P 500 stock index) could have occurred by chance with probability equal to 4 ! $\times 4 ! / 8$ ! or only .0143 .

This evidence is quite consistent with the 1986 Tax Reform Act's having stimulated foreign demand for US business. Moreover, the increase in foreign demand for US businesses was approximately offset by the decrease in domestic demand for US businesses. That is, whereas US purchases of US businesses dropped by roughly $\$ 8$ billion per quarter over the eight quarters surrounding the passage of the 1986 Tax Act, nonUS purchases of US businesses increased by roughly $\$ 8$ billion per quarter. Absent a consideration of how changes in tax rules affected domestic and foreign investors differently, one might have concluded, incorrectly,

20 The increase is $424 \%$ in real terms and $402 \%$ adjusted for changes in the level of the S\&P 500 stock index.

21 Post-reform activity was 3.61 times as high in constant dollar terms and 2.90 times as high adjusted for changes in the level of the S\&P 500 stock index. 
TABLE 5.

MERGER AND ACQUISITION VALUES: NOMINAL DOLLAR, CONSTANT DOLLAR, AND CONSTANT STOCK INDEX AMOUNTS QUARTERLY FIGURES: $1985-4$ THROUGH 1987-4

US PURCHASES BY NON-US COMPANIES ONLY

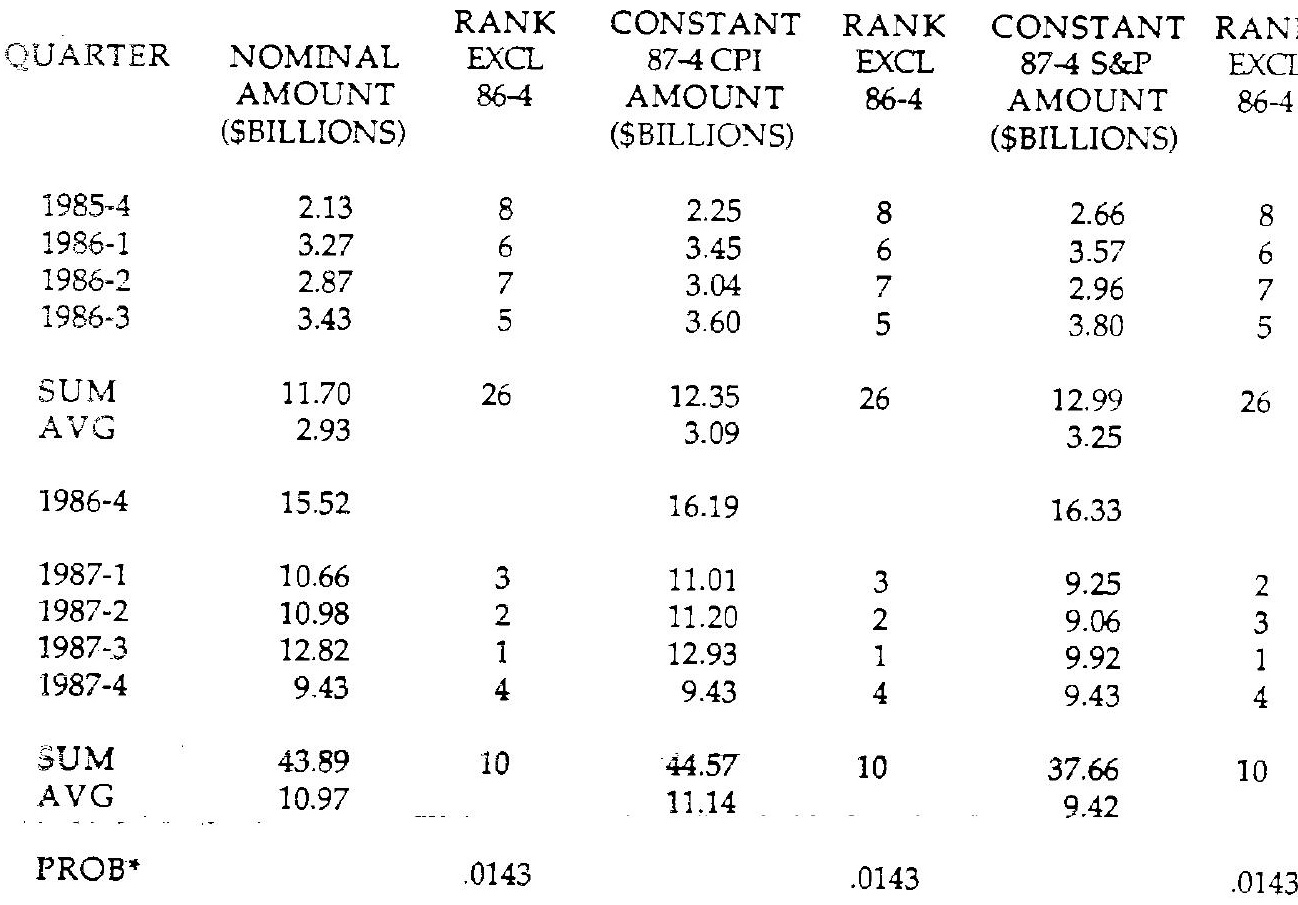

* PROB DENOTES THE PROBABILITY THAT THE SUM OF THE RANKS IN THE FOUR QUARTERS PRECEDING 1986-4 COULD BE AS HIGH OR HIGHER THAN THE SUM OF THE RANKS IN THE FOUR QUARTERS SUCCEEDING 1986-4 BY CHANCE ALONE.

DATA SOURCES: MERGERS \& ACQUISITIONS FOR NOMINAL VALUES INDUSTRY WEEK FOR CONSUMER PRICES

IBBOTSON ASSOCIATES (STOCKS, BONDS, BILLS AND INFLATION) FOR S\&P 500 INDEX VALUES 
that the 1986 Act was accompanied by only a transitory shift in demand for mergers and acquisitions during the fourth quarter of 1986.

The argument that the 1986 Tax Act should have increased foreign investment in the US due to the elimination of tax preferences like investment tax credits and accelerated depreciation runs in reverse in 1981. The Economic Recovery Tax Act (ERTA) of 1981 accelerated depreciation schedules sharply and liberalized investment tax credits somewhat. It is worth noting that foreign acquisitions dropped very sharply in the post-ERTA period, both in absolute dollar terms and relative to total acquisitions. Whersas foreign acquisitions of US companies to total acquisitions was less than $8 \%$ in the post-ERTA/pre-1986 Tax Reform Act period, it was over $20 \%$ of the total both immediately before ERTA and immediately after the 1986 Tax Act.

The analysis above ignores other factors that may have contributed to the surge in foreign acquisitions of US businesses in the fourth quarter of 1986. For example, concern by foreign investors over increasing trade restrictions may have prompted acquisitions by foreign manufacturers that sell to US consumers. Another factor is the changes in the magnitude of the trade deficit, although this is not entirely independent of the amount of foreign acquisitions. A related factor is currency exchange rates. Several recent papers document an association between foreign direct investment in the US and the exchange rate between the dollar and other major foreign currencies. 22 In particular, foreign direct investment apparently increases when the dollar is relatively weak, and conversely, although this would not be expected in perfect capital markets.

What is particularly interesting is that the dollar was relatively very strong during the several years immediately following the passage of the 1981 Tax Act and was very weak in the period surrounding the 1986 Tax Act. Consequently, we are faced with an identification

22For example, see Caves (1988), Froot and Stein (1989) and Slemrod (1989). 
problem in sorting out the independent contribution of tax rule changes and exchange rate changes on acquisition behavior of foreign investors.

But it is also interesting to note that Froot and Stein (1989) find that the relation between exchange rates and foreign direct investments in the US applies to the manufacturing sector but not the nonmanufacturing sector. Since it is the manufacturing sector where the investment tax credit and depreciation rule changes are most important, this lends further credence to the role of taxes.

In addition, the weakness of the dollar surrounding passage of the 1986 Tax Act began in 1985. The fact that such a dramatic shift in foreign acquisition activity began during the fourth quarter of 1986 rather than earlier is further evidence suggesting the importance of taxes.

It is also worth noting that Froot and Stein find that the relation between foreign direct investment and exchange rates is not significant for the UK, Canada, or Japan. And while it is significant for West Germany, the coefficient is only one-ninth as large as for the US. The one indication in Froot and Stein that exchange rates are important in explaining foreign direct investment in the US is that the relation holds strongly during the 1970 s, where tax changes are not terribly significant in the US.

Caves (1988) also documents an inverse relation between foreign direct investment and the following variables: equity security prices in the foreign-investor (source) country relative to the US; GNP of the source country; and lagged profitability of foreign direct investments in the US. On the other hand, exchange rate expectations was not found to affect foreign direct investments. 


\section{Concluding Remarks}

We have presented evidence that tax rule changes in the 1980 s are associated with economically important shifts in merger and acquisition activity in the US. Moreover, foreign acquisitions and domestic acquisitions are affected very differently and in ways predicted by our arguments. While our focus is on transactions that shift corporate control, portfolio investments are also of interest and represent an area for future research. ${ }^{23}$ Also of interest is a study that breaks out data by industry and by country. This would not only increase the number of degrees of freedom in the data (enabling tests that control for certain nontax factors affecting transactions), it would also enhance the internal validity of the inferences since our analysis suggests that behavior should vary in predictable ways across both industries and countries.

\footnotetext{
${ }^{23}$ As an indication of what can be studied, the Deficit Reduction Act of 1984 eiminated withholding taxes on newly-issued US bonds purchased by foreign investors. Bonds purchased by foreign investors skyrocketed, from less than half a billion dollars per quarter over the preceding decade to more than ten billion dollars a quarter over the ensuing three years.
} 


\section{Appendix 1.}

\section{A Digression on Tax Rules for Mergers and Acquisitions}

An acquiring corporation can structure the acquisition of another corporation (the target company) as either a taxable purchase or a tax-free reorganization. In either case, the acquiring corporation can buy the assets or the stock of the target.

If a corporation sells assets, a gain or loss is normally recognized by the selling corporation. No gain or loss is recognized by the shareholders of the selling corporation, however, unless the corporation distributes sales proceeds to shareholders. In this nonliquidating sale, the selling corporation realizes gain or loss equal to the difference between the sale price and the tax basis of the asset. For depreciable assets, if the sale price is below their tax basis, the corporation realizes an ordinary loss under Section 1231. The corporation must pay a tax at ordinary rates, however, on any gain (that is, the difference between the sale price and the tax basis) if the gain is less than the accumulated depreciation on the asset (Section 1245). Prior to the $1986 \mathrm{Act}$, a sale of nonresidential real estate resulted in no recapture of depreciation, however, if straight-line depreciation was used. If the gain on the sale of the asset exceeded the accumulated depreciation, this excess was taxed to most corporations at a $28 \%$ marginal (capital gains) rate prior to 1988 and at normal rates of $34 \%$ beginning in 1988 . Corporations selling assets for a price in excess of tax basis now pay tax at ordinary rates on the entire gain in most cases. Section 47 requires the recapture of investment tax credits on the sale of assets prior to the required holding period, the amount of recapture depending upon how long the assets were held.

Prior to the $1986 \mathrm{Act}$, a corporation could liquidate (under Section 337) and avoid paying a corporate-level capital gains tax on the sale of its assets. This was called the General Utilities doctrine. Prior to the $1984 \mathrm{Act}$, a corporation could sell an asset for debt (an 
installment sale) and defer recognition of the tax on both the capital gain and any recapture of depreciation. The deferred tax was payable only as principal payments were received on the note. If the firm subsequently liquidated, and its shareholders received this note in liquidation, the shareholders would continue to defer recognition of the tax just as the corporation would have if it had not liquidated. Following the passage of the 1984 Act, corporations could no longer defer tax on the depreciation recapture, and with the 1986 and 1987 Acts, the ability to defer tax on the capital gain with the use of installment sales was virtually eliminated. New techniques for deferral of the gain, however, have arisen. For further discussion see Scholes and Wolfson (1990). Moreover, on the sale of assets, capital gains became taxable at the corporate level whether the firm continued to operate its business or liquidated it. ${ }^{24}$ The 1986 Act also eliminated investment tax credits on substantially all assets placed into service subsequent to January $1,1986$.

When a taxable purchase of assets is effected, the acquiring corporation obtains a tax basis in the acquired assets equal to their fair market value (Section 1012). If appreciated assets are purchased, the tax basis to the buyer is stepped up relative to that existing on the books of the seller. The acquiring corporation depreciates all of the acquired assets using depreciation rules in existence at the date of purchase. Investment tax credit was essentially unavailable on the purchase of used equipment even prior to the passage of the $1986 \mathrm{Act}$.

If a firm liquidated and distributed assets, other than installment notes, to its shareholders, the shareholders recognized capital gain or loss depending on their basis in the stock. Prior to the $1986 \mathrm{Act}$, noncorporate shareholders could exclude $60 \%$ of long-term gains from taxation. Subsequent to the 1986 Act, all of the gain is taxable at ordinary rates. ${ }^{25}$

\footnotetext{
${ }^{24}$ Corporations that liquidate recognize ordinary income on the excess of the value of inventory using the FIFO method over that using the LIFO method. Also, investment tax credits previously claimed on the tax retum may be subject to recapture as in the sale of an asset without a liquidation.

${ }^{25}$ Prior to the $1984 \mathrm{Tax}$ Act, no capital gain was recognized by the corporation in a nonliquidating distribution of appreciated property to its shareholders (although ordinary
} 
Stock acquisitions: Prior to the 1986 Act, if a corporation acquired $50 \%$ or more of the target, only the target's shareholders typically were affected. If the underlying purpose of the acquisition was not deemed to have been tax avoidance (Section 269) the basis in corporate assets of the target was unaffected, and other tax attributes such as net operating loss carryforwards and unused credits remained fully available to the acquiring corporation as long as it continued to operate the business (Sections 382,383 ).

There is, however, an important exception to this treatment. If an acquiring corporation purchases 80 percent of the stock of another corporation, it could elect to treat the stock purchase as a purchase of assets. This is called a Section 338 election. If the acquiring corporation makes this election, the transaction is treated exactly the same as a purchase of all of the assets of the selling firm followed by its complete Iiquidation (Section 337$)^{26}$. This election results in the tax basis of the assets being stepped up or down to fair market value but at the cost of a loss of the tax attributes (e.g., net operating loss and tax credit carryforwards) of the selling firm. 27

As a result, a taxable purchase of stock (a common form of acquisition) does not always result in a change in the basis of assets. For a change to occur, the acquiring corporation must make a Section 338 election. We predict that with the 1986 Act, many more stock transactions will be non-Section 338 elections. This will preserve the old basis and depreciation schedule of the assets of the acquired firm, will avoid recapture and capital gains tax on the sale of these assets, and will permit retention of the firm's tax attributes.

income recapture items did have to be recognized). Generally, the 1984 Act triggered capital

gains taxation of such transactions at the corporate level.
26 Note, however, that if a Section 338 election is made, the purchaser rather than the selier recognizes the recapture income and capital gain on the step up.

27In many situations, it is desirable from a tax-planning standpoint, to step up the basis of some assets but not others. The Tax Equity and Fiscal Responsibility Tax Act of 1982 (TEFRA) introduced a variety of changes that sought to prohibit this under Section 338 . In the sale of stock of an $80 \%$-owned subsidiary, however, Section $338(\mathrm{~h})(10)$ allows a step up in the basis of assets to the buyer and retention of the subsidiary's tax attributes by the seller's consolidated group by treating the transaction as a partial sale of assets by the seller's consolidated group. 
Another important tax reason to acquire a firm is to use net operating loss (NOL) and other carryforwards faster than the selling firm could use these attributes. Faster use typically increases the preserit value of the attribute.

Although a corporation can consolidate the income and losses of affiliated corporations (that are at least $80 \%$ owned) for tax purposes, there are restrictions on the use of accumulated NOLs of an acquired firm. The NOL carryforwards of a newly-acquired affiliate cannot offset income of another member of the group under consolidated retum regulations. The acquired corporation is permitted to use its own NOL carryforwards against only its own income (these are called separate return limitation year (SRLY) rules). Built-in losses (where the fair market value of assets is below their tax basis) are subject to the same limitations. Prior to the 1986 Act, it was quite easy to acquire an NOL affiliate and endow it with income-producing assets to use up its NOL carryforwards at a faster rate. This led to a tightening of the rules under the 1986 Act. Before turning to these new rules, we first discuss tax-free reorganizations, another important way to acquire tax attributes.

Tax-free reorganizations: To qualify for a tax-free reorganization, the shareholders of the acquiring corporation must retain a "continuity of interest" in the combined entity. The acquiring corporation must use stock to acquire the stock or assets of the target corporation (Section 368). A statutory merger (Section $368(a)(1)(a)$ ) is a stock-for-stock-and-cash arrangement, wherein the stock-for-stock portion represents a significant part of the consideration. The selling shareholders pay tax on only the gain or loss from the cash part of the transaction (called boot). A "B"reorganization is a $100 \%$ stock-for-stock transaction. In a ${ }^{n} \mathrm{C}^{n}$ reorganization (Section $368(\mathrm{a})(1)(\mathrm{c})$ ), the acquiring firm uses its stock to acquire the assets of the selling corporation (although up to $20 \%$ of the consideration can be a combination of cash and an assumption of liabilities). Both an $A$ and $C$ reorganization result in the complete liquidation of the acquired firm. 
Generally, no gain is recognized by shareholders who, in a tax-free reorganization, exchange stock solely for stock in a corporation. If the exchange involves boot (such as cash), however, gain (but not loss) is recognized up to the amount of the boot.

The acquiring corporation typically assumes a carryover basis in the acquired assets and retains the tax attributes of the acquired corporation (Section 381). Prior to the 1986 Act, special limitations were invoked on the use of NOL carryforwards in a tax-free reorganization if the selling shareholders retained less than a $20 \%$ interest in the shares of the acquiring corporation (Section 382). In that case, only a fraction of the NOL carryforwards would be retained: the percentage of the new entities' shares retained by the "old" shareholders, divided by $20 \%$, and multiplied by the NOL carryforwards (e.g., a $5 \%$ retained interest resulted in a $25 \%$ retention of the NOL carryforwards). But, this continuity-of-business-interest requirement could often be a voided by merging an NOL firm into a subsidiary of the purchaser. Even so, Section 269 might have been invoked by the service to claim that the merger was tax motivated. For this reason, many firms may have continued to operate unprofitable businesses that they acquired to ward off Section 269 claims. $^{28}$

New Section 382 rules: The 1986 Act added new restrictions on the use of NOL and other carryforwards. Subsequent to 1986 a shift in ownership in the acquired firm of more than $50 \%$ in aggregate by $5 \%$ shareholders causes a limitation to be invoked. As a result of this limitation, the acquiring firm cannot use the NOL carryforwards of the acquired corporation in an annual a mount that is greater than the value of the common stock of the acquired firm (possibly reduced by passive assets and recent common equity increases) multiplied by the applicable federal long-term tax-exempt interest rate at the time of a shift in ownership. Moreover, the acquiring firm must operate the loss affiliate for at least two years to retain its tax attributes, and the annual limitation can only be used to offset income generated by the loss affiliate.

\footnotetext{
28 Instead of selling a corporation with net operating loss carryforwards (NOLs), the NOL corporation could instead acquire a profitable corporation to use up its NOLs.
} 
Generally, the 1986 Act limits severely the use of NOL carryforwards acquired in either a stock purchase (with a non 338 election), a tax-free reorganization, or an asset reorganization. 


\section{References}

Auerbach, Alan J. and Poterba, James M., "Tax Loss Carryforwards and Corporate Tax Incentives," in The Effects of Taxation on Capital Accumulation, edited by Martin Feldstein (University of Chicago Press), 1987, pp. 304-342.

Auerbach, Alan J. and David Reishus, "The Impact of Taxation on Mergers and Acquisitions," in Mergers and Acquisitions, edited by Alan J. Auerbach (University of Chicago Press), 1988, pp. 69-85.

Caves, Richard E, "Exchange-Rate Movements and Foreign Direct Investments in the United States," Discussion Paper No 1383 (Harvard Institute of Economic Research), May 1988.

Froot, Kenneth A. and Jeremy C. Siein, "Exchange Rates and Foreign Direct Investment: An Imperfect Capital Markets Approach," (Unpublished working paper), February 19, 1989.

Fullerton, Don, Robert Gillette, and James Mackie, "Investment Incentives Under the Tax Reform Act of 1986," in Compendium of Tax Reseatch (Office of Tax Analysis), 1987, pp. $131-171$.

Gilson, Ronald J., Myron S. Scholes, and Mark A. Wolfson, "Taxation and the Dynamics of Corporate Control: The Uneasy Case for Tax-Motivated Acquisitions," in Knights, Raiders and Targets: The Impact of the Hostile Takeover, edited by John C. Coffee, Jr., Louis Lowenstein, and Susan Rose-Ackeman (Oxford University Press), 1987.

Jensen, Michael C., "The Takeover Controversy: Analysis and Evidence," Midland Corporate Finance lournal (Summer 1986), pp 1-27. 
Kaplan, Steven, "Managment Buyouts: Evidence on Taxes As a Source of Value (Harvard Working Paper), November 1987.

Kleinbard, Edward D and James A. Duncan, "Tax Planning for Cross-Border Acquisitions," The National Law Journal (May 18, 1987), pp 24-27.

Schipper, Katherine and Abbie Smith, "Corporate Income Tax Effects of Management Buyouts" (University of Chicago Working Paper), June 1988.

Schipper, Katherine and Rex Thompson, "Evidence on the Capitalized Value of Merger Activity for Acquiring Firms," Journal of Financial Economics (April 1983), pp. 85-119.

Scholes, Myron S., Eric Terry, and Mark A. Wolfson, "Taxes, Trading, and the Value of Real Estate," Lournal of Accounting Auditing and Finance (1989), forthcoming.

Scholes, Myron S. and Mark A. Wolfson, "Taxes and Organization Theory," (Stanford working paper), April 1987.

Scholes, Myron S. and Mark A. Wolfson, Taxes and Corporate Financial Strategv: A Global Planning Approach (Prentice Hall, 1990).

Slemrod, Joel B., "Tax Efiects on Foreign Direct Investment in the U.S.: Evidence from a CrossCountry Comparison," (University of Michigan and NBER working paper), January 1989.

Taggart, Robert A., Jr. "The Growth of the 'Junk' Bond Market and Its Role in Financing Takeovers," in Metgets and Acquisitions, edited by Alan J. Auerbach (University of Chicago Press), 1988, pp. 5-24. 